\title{
Tüketim Karşıtı Yeni Yaşam Biçimi Köye Dönüşün Medyada Sunumu: Yeni Köylüler Örneği
}

\author{
Şefika Özdemir (Dr. Öğr. Üyesi) \\ Süleyman Demirel Üniversitesi İletişim Fakültesi \\ sefikaozdemir@sdu.edu.tr \\ Başvuru Tarihi: 03.03.2020 \\ Yayına Kabul Tarihi: 02.05.2020 \\ Yayınlanma Tarihi: 24.07.2020 \\ https://doi.org/10.17680/erciyesiletisim.698143
}

\section{Öz}

Tüketim kültürünün yarattığı aşırı tüketim maddi doyumsuzluk, kaynakların tükenmesi, kültürel yozlaşma, çevre kirliliği ve ürün bolluğunun yarattığı kararsızlık gibi olumsuz etkiler yaratmaktadır. Bu etkilerin farkına varan tüketiciler tüketim karşıtlığı kapsamında ürün ve markaların boykot edilmesinden karşı reklamlara, çevre protestolarından freegan akıma kadar çeşitli boyutlarda aşırı tüketime ve modern yaşamın yarattığı koşullara tepki göstermektedirler. Tüketim karşıtı söylem sürdürülebilirlik, organik üretim, sürdürülebilir tüketim, çevre bilinci, konuları üzerinden de şekillenmektedir. Tüketicilerin tüketim karşıtı eğilimleri, ürün tercihlerinden tüketimi azaltan yeni yaşam tasarımlarına ya da mekansal olarak şehirlerden doğaya yeni yaşam biçimleri kuracak şekilde farklı uygulamalarda kendini göstermektedir. Tüketicilerin tüketim karşıtı eğilimlerinin oluşmasında medyanın sunduğu içerikler tüketim karşıtlığına atfedilen değerleri ve imajları ileten bir söylem yaratmaktadır. Bu bağlamda araştırmada medyanın ürettiği içeriklerde hangi temaları kullanarak tüketicileri tüketim karşıtlığı yönünde teşvik ettiğinin ortaya konulması amaçlanmıştır. Araştırmada önceden belirgin olmayan temaların ve boyutların ortaya çıkarılmasına ve toplanan verilerin derinlemesine analiz edilmesine imkan vermesi nedeniyle içerik analizi tercih edilmiştir. İçerikleri bağlamında TRT Belgesel kanalında yayınlanan "Yeni Köylü" programı, CNNTÜRK kanalında yayınlanan "Yeşil Doğa" programı ve TRT Belgesel kanalında yayınlanan "Bi Çiftlik" programı incelenmiştir. Program içerikleri deşifre edilerek ortaya çıkan nitel verilerin çözümlenmesinde tematik kodlama yapılmıştır.

Anahtar Kelimeler: Tüketici Davranışları, Tüketim Karşıtlı̆̆ı, Sürdürülebilir Tüketim, Medya, İçerik Analizi. 


\title{
Anti-Consumption New Living Form Return to Village Presentation in the Media: A Case of New Villagers
}

\author{
Şefika Özdemir (Asst. Prof. Dr.) \\ Süleyman Demirel University Faculty of Communication \\ sefikaozdemir@sdu.edu.tr
}

Date Received: 03.03.2020

Date Accepted: 02.05.2020

Date Published: 24.07.2020

https://doi.org/10.17680/erciyesiletisim.698143

\begin{abstract}
Excessive consumption created by the consumption culture creates adverse effects such as material dissatisfaction, resource depletion, cultural degeneration, environmental pollution, and instability caused by product abundance. In the context of anticonsumption, the consumers who realize these effects react to over-consumption in various dimensions and the conditions created by modern life, from the boycott of the products and brands, environmental protests to freegan movement, Anti-consumption discourse is also shaped through the issue of sustainability, organic production, sustainable consumption, environmental awareness. Anti-consumption tendency of the consumers shows themselves in different applications, from product preferences to new consumption designs that reduce consumption, or to create new lifestyles from cities to nature spatially. The content presented by the media in creating the anti-consumption tendencies of consumers creates a discourse that conveys the values and images attributed to anti-consumption. In this context, it was aimed to reveal, using the content produced by the media, which themes encourage consumers in the direction of anti-consumption. In this study, content analysis was preferred because it allows us to reveal previously unclear themes and dimensions and to analyze the collected data in depth. In the context of its contents, the program "Yeni Koylu" broadcast on the TRT Documentary channel, the "Yesil Doga" program broadcast on the CNN TURK channel and the "Bi Ciftlik" program broadcast on the TRT Documentary channel were examined. Thematic coding was used to analyze the qualitative data that came out by deciphering the program contents.
\end{abstract}

Keywords: Consumer Behavior, Anti-Consumption, Media, Sustainable Consumption, Content Analysis. 


\section{Giriş}

Yirminci yüzyıl tüketici haklarını tanımlama ve elde etme girişimleri kapsamında tüketici hareketleri ile ilgili olmuştur. Son yıllarda ise çevre, aşırı tüketim, yaygınlaşan reklamlar gibi konuların etkisiyle pazarlama uygulamalarına karşı oluşan şüphecilik, yeni ürün hızı, aşırı tüketim mesajlarıyla çevrilme, tüketicilerin edilgen konumdan etken konuma geçmek istemesi tüketim karşıtı hareketleri arttırmaktadır. Tüketim karşıtı hareketler etik ve ekolojik kaygllarla ürün seçimleri yapmaktan genel olarak tüketimi reddetme yada belirli ürün gruplarını boykot etmeye kadar çeşitlenmektedir. Tüketim karşıtı hareketlerin yayılması kapsamında adil ticaret (Fair Trade), yeni kentleşme, gönüllü sadelik, bir şey almama günü, McLibel destek kampanyası, megamağaza karşıtları protestoları, yavaş gıda hareketi (Ritzer, 2017, s. 288-292), satışları geriletme bildirgesi, tüketim karşıtı yayınlar (Adbusters) ve belgeseller, uluslar arası satın almama günü ve televizyon kapatma haftası, gibi uygulamalar görülmektedir (Fournier, 1998; Craig-Lees \& Hill, 2002, s. 187 188; Binkley \& Littler, 2008, s. 520). Tüketim karşıtı söylem küresel tüketimciliğin sosyal eşitsizlik yarattığını, kültür üzerinde yıkıcı etkiye sahip olduğunu ve küresel "hamburger toplumunun" tüm değerleri yavaş yavaş yok ettiğini iddia etmektedir (Cherrier, 2009, s. 184). Tüketicilerin bu uygulamalara yönelmesinde, sahip oldukları maddiyat ve zenginlik ile yaşadıkları stresin, mutsuzluğun ve kendini gerçekleştirememenin üstesinden gelemediklerini anlamaları yer almaktadır (Zavestoski, 2002a, s. 154). Bununla birlikte tüketim karşıtı uygulamalar; sürdürülebilirlik, organik üretim, ekolojik ayak izi, çevre bilinci, doğa ve küresel uyarı söylemleri üzerinden de şekillenmektedir (Black ve Cherrier, 2010, s. 441). Bununla birlikte gelecek nesillerin ihtiyaçlarını tehlikeye atmadan temel ihtiyaçlara cevap veren ve daha iyi bir yaşam kalitesi getiren, doğal kaynakların ve zehirli malzemelerin kullanımını ve aynı zamanda yaşam döngüsü boyunca atık ve kirletici madde emisyonlarını en aza indiren ilgili ürünlerin kullanılması anlamında sürdürülebilir tüketim (Seyfang, 2006, s. 384)'de, tüketim karşıtlığının farklı boyutlarında ortaya çıkan yeni bir tüketici profilinin tüketim eğilimini göstermektedir.

Tüketimciliğin eleştirisini sunan içerikler ana akım medyada yani en çok satılan kitaplarda, dergilerde, sosyal medyada, televizyon programlarında ve belgesellerde, filmlerde popüler alanlarda şekillenmekte ve bu yönüyle tüketim karşıtlığı bir ucundan popüler kültüre girme yolunda da ilerlemektedir (Binkley ve Littler, 2008, s. 520). Bu bağlamda araştırmanın ilk kısmında tüketim karşıtlığı ve bu kapsamda ortaya çıkan tüketici tipolojileri, bu tüketiciler için bir rehber niteliğinde sürdürülebilir tüketim, tüketim karşıtlığının farklı biçimlerini sunarak tüketicilere bu konuda iletiler sunan medyaya ilişkin kavramsal çerçeve ele alınmıştır. Araştırmanın uygulama kısmında medyanın tüketicilere ilettiği kodları çözümlemek amacıyla üç farklı televizyon programının ikişer bölümü nitel içerik analizi kullanılarak çözümlenmiş, bulgular yorumlanmıştır.

\section{Tüketim Karşıtlığı}

Tüketim karşıtlığı tüketime karşı olma anlamını taşır ama bu tüketim kavramı tüm canlıların oksijen, su, vb. tükettiği fizyolojik tanımların aksine, iş söylemine özgü bir tanımdır yani odak nokta tüketim sürecine karşı olan olgularla ilgilidir (Lee, Roux, Cherrier ve Cova, 2011). Tüketim karşıtı olan eğitimli ve tepkili tüketicilerin gündelik tüketim alışkanlıkları ve gerçeklikleri son zamanlarda ilgi gören araștırma alanlarındandır (Portwood-Stacer, 2012; Cherrier ve Gurrieri, 2013; Chatzidakis \& Lee, 2013; Hoffmann \& Lee, 2016; Nepomuceno, Rohani, \& Grégoire, 2017; Ashraf, Joarder \& Ratan, 2019). Sürdürülemez aşırı tüketimin dünyadaki yaşam kalitesine ve çevreye zarar vermesi tüketim karşıtı eğilimleri tetiklemiştir. Zavestoski (2002b, s. 122), tüketim 
karşıtı tutumların birçok farklı şekilde ortaya çıktığını belirtir. Medyada dayatılan güzellik fikrine ilişkin imajların reddedilmesi, kendini ifade etme aracı olarak maddi tüketimin reddedilmesi, tüketim davranışlarını gönüllü sadelik ve etik tüketim uygulamalarıyla değiştirme, pazarlama ve reklam mesajlarının işgal ettiği zihin alanı için mücadele etmek olarak bunları sıralamaktadır. Kozinets, Handelman ve Lee (2010, s. 226) bir fenomen olarak tüketim karşıtlığının marka karşıtı söylemden aktivist hareketlere, küreselleşme karşıtı gösterilerden ütopik topluluklara, kültür bozuculardan gönüllü sadelik kitap kulüplerine, sürdürülebilir ve sosyal pazarlama uygulamalarına kadar geniş bir alanı içerdiğini belirtir. Lasn'ın (2004) ifadesiyle bu medyanın, şirketlerin ve markaların yarattığı tüketim kültürüne karşı direnç gösteren bir toplumsal harekettir. Cherrier (2009, s.183) tüketim karşıtı söylemin kontrolsüz bir dünyada yaşama ve duygusal yalnızlık olmak üzere iki ana tema altında ortaya çıktığını belirtir. Kontrolsüz bir dünyada yaşam teması mevcut ekolojik konuları ve sosyal eşitsizliği ifade ederken, duygusal yalnızlık tüketim bağımlılığını ve anonimliği ifade etmektedir. Lee, Cherrier ve Belk (2013, s. 187) tüketim karşıtı söylemlerin, tüketimciliğe rehberlik eden davranış, ilke ve değerlerin dışındaki yaşam biçimlerini, uygulamaları ve örnekleri tartıştığı için gelecek için umut verici bir yön çizdiğini belirtir. Bireyler tüketmemeyi seçerek kendi yaşam hikâyelerinin baş aktörü olmanın ötesinde toplumun ve gezegenin değişim ajanı olacaklardır. Bu açıdan tüketim karşıtı söylemlerin, seçeneksizliğin ve tüketimin reddedilmesinin toplumsal ve kültürel değişimi sağlamada oynayabileceği role ilişkin büyük bir farkındalık sağlayacağına işaret etmektedir.

\subsection{Tüketim Karşıtı Tüketici Tipolojileri}

Tüketim karşıtlığı söylemsel alanını tanımlamak karmaşık ve zordur. Binkley (2008, s. 601)'e göre tüketim karşıtı uygulamalar yeni kimlik ve günlük yaşam uygulamaları üretmek için mistik, teröpatik ve yarı tıbbi unsurlar, alternatif eğlence ve mülkiyet kavramları, mülklerin biriktirilmesi, kullanılması ve tekrar kullanılması, ayrıca ev yapma, ziraat, ulaşım, turizm ve zaman yönetimi gibi bir çok alanda yeni yaklaşımlar içermektedir. Tüketim karşıtı eğilimler farklı güdülerden kaynaklanarak farklı biçimlerde kendini göstermektedir. Iyer ve Munch (2009) küresel etki tüketicileri, gönüllü sadeciler, aktivistler ve sadık olmayan tüketiciler olmak üzere dört tip tüketim karşıtı tüketici tanımlamaktadır. Küresel etki tüketicileri dünyanın ve toplumun yararı için genel tüketim seviyesini azaltmak ile ilgilenmektedirler. Bu tüketicilerin tüketim karşıtlığının temel iki sebebi çevresel kaygılar ve maddi eşitsizliktir. Basit yaşam isteyen tüketiciler tüketim toplumunun hızlı tempolu yaşamını bırakarak daha basit yaşamayı ve daha az tüketim odaklı bir yaşamı hedeflemektedirler. Pazar aktivistleri, bir ürün ya da markayı belirli bir sosyal probleme (çevresel bozulma, markanın yarattığı olumsuz sosyal davranışlar gibi) neden olabileceğini düşünerek kullanmaktan kaçınırlar. Sadık olmayan tüketiciler ise belirli bir marka ya da ürüne sadakat göstermekten kaçınırlar.

Çevresel kaygıları olan ve sürdürülebilir bir yașam arzulayan tüketicilerin bir kısmı satın alma kararlarında "çevreyle dost", "ekolojik ürün” ve“yeşil ürün” etiketlerine sahip ürünleri tercih etmeleri gerektiğinin farkında olmalarına rağmen gerçek yaşamda bunu uygulayamamaktadır. Çevresel kaygıları olan bir kısım tüketici içinse bu tür ürünlerin sürdürülebilirliği sağlamada bir etkisi yoktur (Black ve Cherrier, 2010, s. 441-442). Tüketiciler geleneksellik (Bayat ve Sezer, 2018), kendini gerçekleştirme, çevrecilik, hümanizm, kendi kaderini kendi belirleme, maneviyat gibi değerlerin etkisiyle gönüllü sade yaşamı tercih etmektedir (Craig-Lees ve Hill, 2002, s.191). Shama (1981, s. 121) gönüllü sadeliğin, 1970’lerden sonra ekonomik çevrede yaşanan kıtlık, enflasyon ve 
durgunluk gibi değişimlerin tüketici tutumları ve davranışları üzerinde yarattığı etki olarak ortaya çıktığını belirtir. Elgin ve Mitchell (1977, s.13) gönüllü sadeliği insanın iç dünyasında zengin, dış dünyasında ise basit bir yaşamı sürdürmesi olarak tanımlar. Bu yaşam biçiminde tüketirken tutumlu olma, ekolojik konulara önem verme ve kișisel gelişime odaklanmanın benimsendiğini belirtir. Gönüllü sadeliği tercih eden insanlar mümkün olabildiği kadar doğal yaşamaya çalışırlar. Gönüllü sadelik modern toplumun sorunlarına yönelik kapsamlı bir toplumsal ve bireysel tepkidir. McDonald, Oates, Young ve Hwang (2006, s.25 )'a göre gönüllü sadelik bir inanç sistemidir ve gösteriş tüketimine karşı oluşan bir alternatif kültür pratiğidir. Gönüllü sade yaşam ve pratiği tüketimin reddedilmesinin merkezinde yer alır. Gönüllü sade yaşam, maddi olmayan tatmini, insana ve doğaya değer vermeyi, kişisel gelişimi maddiyata sahip olmanın üstünde tutmaktadır. Tüketicilerin bu eğilimlerinin inanç boyutu dikkate alındığında Protestan ahlak anlayışı kapsamında püritan etik, çalışma ve biriktirmeyi Protestan inanç sistemi içinde kutsarken harcamaya ve gösteriş tüketimine karşı çıkmıştır (Bozkurt, 2005, s. 54-62). İslam inancında da harcamalarda iktisatlı olmak, israf ve gösterișten uzak, cimrilik ya da istifleme yapmayan dengeli bir yaşam emredilmiştir. Meşru ihtiyaçlar karşılandıktan sonra artan geliri israf etmeden lükse ve göşterişe yönelmeyerek tüketimi kontrol altında tutma tavsiye edilmektedir (Akar, 2018, 37-39). Lee vd. (2011), Tüketim karşıtlığı kapsamında tüketici davranışlarını üç grupta değerlendirir: reddet, kısitla ve geri kullanım.

- •Reddetme süreçlerinde, bireyler belirli ürünleri tüketim döngülerinden kasıtlı ve anlamlı bir şekilde çlkarırlar; örneğin, fonksiyonel, sembolik veya etik nedenlerden dolayı bazı markaları kullanmayı reddetmek.

- •Kısıtlama fikri, tamamen tüketimin önlenmesi mümkün olmadığında tüketimin azaltılması ve sınırlandırılması; örneğin, elektrik veya su kullanımını kısıtlamak.

- •Reddetmek bazı malların tüketiminden kaçınmak ve kısıtlamak bazı malların azaltılmasıyla ilgili olmakla birlikte, geri kazanım, satın alma, kullanma ve elden çıkarma işlemleriyle ilgili ideolojik bir değișimi temsil eder.

Tüketim karşıtlığının farklı bir biçimi olarak son zamanlarda öne çıkan Freeganizm akımını atılan yiyecekleri tüketerek çevresel etkiyi an aza indirmeye çalışan sosyal, ekonomik ve politik bir eğilimi ifade etmektedir. Freeganizm, İngilizce karşılığı bedava anlamına gelen 'free' ve hayvansal herhangi bir ürünü tüketmeye karşı olmak anlamına gelen 'vegan' sözcüklerinin birleşiminden türemiştir (Pentina ve Amos, 2011, s. 1769). $\mathrm{Bu}$ akım, aşırı ve gereksiz tüketimin engellenmesiyle birlikte çevre temizliği konusuna da dikkat çekmektedir. Bu akımı benimseyenler sadece işsiz kişilerden oluşmamakta aynı zamanda bu topluluğun üyeleri arasında avukatlar, taksi şoförleri, yöneticiler ve öğrenciler bulunmaktadır. Bu kişiler sosyal medya kanalıyla çöpten çıkarılan gıdaların nasıl faydalı bir besin olarak kullanılacağına dair yemek tarifleri de yayınlamaktadırlar. $\mathrm{Bu}$ akımının üyeleri, yeryüzünde sürmekte olan aşırı tüketim ve israfın önlenmesine yönelik bir farkındalık oluşturmaya çabalamaktadırlar. Sürdürülebilir bir dünya için israf ve tüketimin minimize edilmesine ve var olan kaynakların doğru ve etkin kullanılmasına vurgu yapmaktadırlar (Aksoy ve Solunoğlu, 2015, s.168-170).

Doğal kaynakları koruma, kirliliği önleme ve ekolojik etkiyi dikkate alması açısından tüketim karşıtı eğilimler sürdürülebilir tüketim davranışının bir unsuru olarak görülmektedir (McDonald vd 2006, s. 6). Gelecek nesillerin en azından şimdiki şartlarda ya da daha iyi yaşam sürebilmeleri adına mevcut kaynakların en iyi şekilde kullanılması 
ve değerlendirilmesi noktasında sürdürülebilirlik kavramı önem taşımaktadır. Sürdürülebilir tüketim ulusal ve uluslararası alanda yeni yüzyılın temel politika hedefi haline gelmiştir (UNEP, 2015; UN, 2020; Jackson ve Michaelis, 2003).

\subsection{Sürdürülebilir Tüketim ve Tüketici-Vatandaş}

Son yıllarda tüketicilerin tüketimi azaltma, gönüllü sade yaşamı tercih etme ve marka karşıtı eğilimleri, sürdürülebilir tüketim kavramının farklı çevrelerce dikkate alınmasını sağlayacak bir yol açmaktadır. Birleşmiş Milletler Çevre Programı'nın tanımına göre sürdürülebilir tüketim, tüketim ve üretim sistemlerinden kaynaklanan olumsuz çevresel etkileri en aza indirmeye çalışırken, herkes için yaşam kalitesini arttırmaya yönelik bütüncül bir yaklaşımdır. Tüketim modellerinin yaşam kalitesinden ödün vermeden daha düşük enerji ve malzeme yoğunluğuna sahip mal ve hizmet gruplarına doğru kaydırılmasını teşvik etmeyi hedeflemektedir (UNEP, 2015,s. 10). Sürdürülebilir tüketim anlayışının merkezinde tüketici davranışı ve yaşam tarzlarına mı, yoksa sürdürülebilir ürünlerin üretiminin mi yer alacağı tartışılmaktadır. Bununla birlikte sürdürülebilir tüketimin, tüketimin sınırlanması ya da daha farklı bir tüketim şekli olması yönündeki tartışmalar konuyu sadece sürdürülebilir ürünlerin tüketilmesine indirgemektedir (Jackson ve Michaelis, 2003, s.15 ). Bu alternatif sürdürülebilir tüketim anlayıșı, gelişmiş ülkelerdeki tüketicilerin tüketimini azaltmayı ve refahın sosyal ve çevresel yönlerine değer veren yeni sosyal ve ekonomik kurumlar kurmak için "refah" ve "ilerleme" kavramlarının yeniden tanımlanmasını gerektirmektedir (Seyfang, 2006, s. 385)

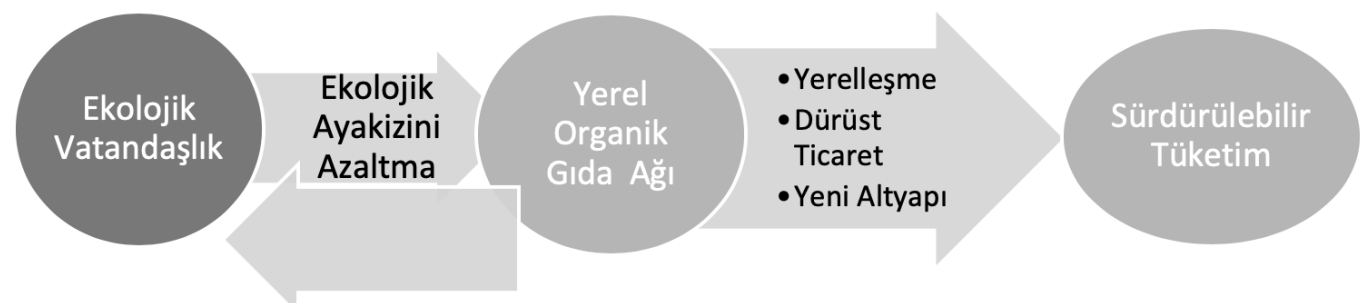

Şekil 1: Ekolojik Vatandaşlık ve Sürdürülebilir Tüketim İlişkisi Kaynak: (Seyfang, 2006, s. 385)

Burada amaç, sürdürülebilir tüketim konusuna geniş çapta yaklaşmaktır. Sürdürülebilir bir tüketime doğru ilerlemek sonunda birey için bir görev olabilir, ancak bununla ilgili tartışmanın, onu çevreleyen yapısal faktörleri de içine alacak şekilde genişlemesi gerekmektedir. Yasal ve örgütsel değișiklikler davranış değişikliğini teşvik edebilir, ancak bu tür değişiklikleri başarmak için tüketici olan bireylerin daha ziyade vatandaş olarak katılımını gerektirmektedir (Sanne, 2002, s.274). Tüketim karşıtı hareketler, tüketicilerin vatandaş olarak topluma ve çevreye karşı sorumlulukları tarafından güdülenmektedir. Sagoff (2007, s. 60), birey olarak istediklerimiz ile vatandaş olarak inandıklarımız arasında çatışma yaşandığını belirtmektedir. Bu çatışma sadece zengin ve fakir, gelecek ve geçmiş arasındaki bir malların paylaşımı sorununun ötesinde bir etik boyut içermektedir. Daha doğrusu bu durum, isteklerin nasıl tatmin edildiği ve inançlarla nasıl yaşanıldığıyla ilgilidir. Bir vatandaş ya da etik ve politik bir toplumun üyesi olarak tüketicilerin alışveriş yaparken yada sebze seçerken duygusal, ideolojik, kültürel, estetik ve etik her türlü değerle çatışan şekilde ortaya çıkan çıkarlarından endişelenilmektedir. Dobson (2003, s. 89-90), çevresel ve ekolojik vatandaşlık şeklinde birbiri yerine az çok yer değiştirebilen iki kavramdan bahseder. Reid ve Taylor (2000)'a göre ekolojik vatandaşlar, kendi evlerinde, komşuluklarında ve sevdiklerinde çevresel zararın farkına varıp Amerikan rüyası mantıkları yıkılana kadar egemen anlatılar (tüketim toplumu) içinde oldukça iyi 
bir yaşam sürmektedirler (alıntılayan Dobson, 2003, s. 93). Serbest piyasa ekonomisinde bireysel tüketici-vatandaşların topluma ve çevrelerine karşı görevleri vardır, ancak ailelerine ve kendilerine karşı da tüketimi arttıracak görevleri vardır ve bu görevlerin bazıları çatışabilir. Sürdürülebilir tüketim ile ilgili tüketici-vatandaş davranışını neyin tetiklediğini ve engellediğini anlamak için insanların bu görevleri kişisel çıkarlarla nasıl dengeledikleri ve ayrıca tüketicinin şüpheleri, belirsizlikleri ve çatışmaları hakkında daha fazla araştırmaya ihtiyaç vardır. Örneğin, birçok insan, evlerinde enerji tasarrufu sağlayan veya eko-etiketli ürünler satın alarak, çevre dostu bir şekilde hareket etme yükümlülüğü hissetmektedir (Prothero, Dobscha, Freund, Kilbourne, Luchs, Ozanne ve Thøgersen, 2011, s. 33). Ancak bu uygulamaların merkezinde, bu tüketim karşıtı yaşam tarzı söylemlerinin merkezinde, tüketicinin öznelliğinin temel bileşenlerinin bir aracı olduğu görülmektedir (Binkley, 2008, s. 601-602). Tüketim karşıtlığının geniş tüketici kesimlerinde yayılmasında medyanın önemli bir rolü olduğu görülmektedir.

\subsection{Tüketim Karşıtlığı ve Medya}

Medya bireyleri etkilemesinin yanında bireylerin kültürlerini, bilgi birikimlerini, toplumun ilke ve değerlerini de etkilemektedir. Medya, izleyicilerin davranış biçimlerinde seçim yapabilecekleri bir dizi imge, fikir ve değerlendirmeyi ortaya koyarak bu etkiyi yaratmaktadır (McQuail ve Windahl, 1993, s. 98). Farklı medya kanallarında tüketicilerin tüketim karşıtı eğilimlerini yansıtan içerikler yer almakla birlikte son yıllarda bu içerikler artmıştır. $\mathrm{Bu}$ içerikler tüketici eğilimlerini etkilemede rol modeller sunarken bazı akımların yaygınlaşmasında araç rolü üstlenebilmektedir. Bu noktada aşırı tüketim ve bunun insan sağlığına, doğaya ve diğer insanlara doğrudan veya dolaylı etkilerini anlatan ya da eleștiren bazı filmler: Wall-e (2008 animasyon çizgi film ); They Live (1988), Dövüş Kulübü (1999), Örnek Aile (2009), Yedinci Kıta(1989), Truman Show (1998), Özgürlük Yolu (2007), Loraks (animasyon çizgi film 2012), Entelköy Efeköy’e Karşı (2012), Dondurmam Kaymak (2005) olarak sıralanabilir. No Impact Man Belgeseli (2009), Gerçek Bedel (2015), Daha Azıyla Büyüyün (2012), Bir Dolarla Yaşamak (2013), Minimalizm (2015) gibi bazı belgeseller, Affluenza (1997 TV dizisi) gibi televizyon yapımları aşırı tüketimi eleştirirken daha sade ve az harcama yaparak ihtiyaçlarını gideren tüketicilerin yaşamlarını sunmaktadır. Bunlarla birlikte Adbusters gibi kuruluşların faaliyetleri, Killercoke.org, starbucked.com, Msboycott.com vb. gibi marka karşıtı web siteleri (Krishnamurthy ve Kucuk, 2009), No Logo (2002) gibi kitaplar kendini görünür kılan tüketim karşıtı söylemlerle bir ucundan popüler kültür alanına da girmeye başlamıştır. Geleneksel medyanın yanında yeni medyada da web siteleri "hayalimbiciftlik.com", "baranciftligi.net", "zeytinlibogaz.com", "tatuta.org" vb. modern yaşama alternatif arayan tüketiciler için bir alan sunmaktadır. Bu web sitelerinin ya da programların içerikleri aynı zamanda Instagram hesapları, Facebook adresleri, Youtube yayınlarıyla da izleyicilere ulaşmaktadır. Youtube platformunda " yaşabuhayatı", "buralıyız biz", kasabalı hanım” gibi farklı kanallarda şehir yaşamından uzaklaşıp köye göçmeye ilişkin çeşitli içeriklerde videolar bulunmaktadır. TRT Belgesel kanalının yayınladığı "Bi Çiftlik" (2015-2016) şehirden köylere göç etmiş insan hikâyelerini ele almaktadır. TRT belgesel kanalında 3 bölüm olarak yayınlanan "Yeni Köylü" (2016) programı şehirden uzaklaşıp köye yerleşmiş organik ve doğal bir yaşamı benimseyen yeni köylülerin hikâyelerini ekranlara taşımaktadır. TV360 kanalında yayınlanan "Doğal yaşam” programı kendisini toplumda ekolojik yaşam bilincini oluşturmak ve doğa ile uyumlu yaşamı desteklemekten yola çıkılarak oluşturulan bir "Doğal Hayat" projesi olarak tanımlamaktadır. CNNTÜRK kanalında Güven İslamoğlu'nun sunduğu "Yeşil Doğa” (2011-devam ediyor) programı Türkiye'nin çevre sorunlarını ekrana taşıyarak doğası, insanı, kültürü ve tarihiyle 
Türkiye'nin yeniden keşfini sunmaktadır Bu yapımlar benzer içeriklerle ekranlarda yer almaktadır. Programların konuları her bölüm farklı olmakla birlikte farklı tarımsal ve kültürel üretim modellerini, unutulan kültürel değerler, sağlıklı beslenme, doğal yașam ve sürdürülebilir üretim ve tüketim konularında mesajlar içermektedir. Bu içeriklerin bir kısmı doğada yaşama tutkusu, hayatı sadeleștirmek ve şehirden çıkmak istemekle başlayan yolculukların anlatıldığı hayat hikâyelerini ele alırken izleyenlere de rol modeller sunmaktadır.

\section{Yöntem}

Çalışmada, olayları ve insan deneyimlerini doğal ortamda betimlemeyi ve açıklamayı sağlaması nedeniyle nitel araştırma yöntemi kullanılmıştır. Nitel verilerin analizinde belirgin olmayan temaların ve boyutların ortaya çıkarılmasına ve toplanan verilerin derinlemesine analiz edilmesine imkân vermesi nedeniyle içerik analizi tercih edilmiştir. Nitel verilerin analiz sürecinde ilk olarak verilerin kodlanması, temaların bulunması, verilerin temalara göre düzenlenmesi ve bulguların yorumlama aşamaları dikkate alınmıştır (Yıldırım ve Şimşek, 2016, s. 242-253). İçerik çözümlemesinde ele alınan içeriğin belli niteliklerinin kodlarla temsil edildiği kabul edilir. Amaç her biri bir diğerinden ayırt edilebilir kategorilerin oluşturulmasıdır. Niteliksel veri çözümlemesinde genellikle alt kümeler, tematik (anlamsal/konusal) ve yapısal olarak ilişkilendirilmiş veri dizileri oluşturur. Niteliksel veri çözümlemesinin yaklaşımlarından biri olan tematik kodlama, gözlem ve görüşme çıktılarının çeşitli kavramlar, başlıklar veya temalara göre sınıflandırılmasını içerir (Geray, 2006, s. 175-176). Araştırma kapsamında, araştırmanın sınırlılı̆̆ı nedeniyle içerikleri bağlamında üç program dikkate alınmıştır. TRT Belgesel kanalında yayınlanan "Yeni Köylü" programı, CNNTÜRK kanalında yayınlanan "Yeşil Doğa" programı ve TRT Belgesel kanalında yayınlanan "Bi Çiftlik" programı incelenmiş ve her programdan iki bölüm araştırmaya dahil edilmiştir. Tüketim karşıtlı̆̆ bağlamında köye dönüş hikâyelerini içeren bu videoların doküman incelemesi yapılmıștır. Seçilen bu programların tamamı araştırmacı tarafından deşifre edilerek kişilerin söyledikleri, hangi bilgilerin ortaya çıktığı yazılı hale getirilmiştir. Yazılı hale gelen dokümanlar üzerinden ortaya çıkan anlama göre kodlar oluşturulmuştur. Kodlar arasındaki ortak yönler dikkate alınıp tematik kodlama yapılarak ana tema ve alt temalar belirlenmiștir. Son aşamada ise temalar dikkate alınarak veriler ilişkilendirilip programda yer alan kişilerin konuşmalarından alıntılarla desteklenerek yorumlanmıștır.

Miles ve Huberman (1994, s. 64) araştırmanın güvenilirliği için birden fazla kişinin ayrı ayrı kodlama yapmasını önererek (Güvenirlik= Görüş birliği/Toplam Görüş birliği + Görüş ayrılığı) formülünü sunmaktadır. İç tutarlılık açısından araştırmacılara birkaç gün ara vererek tekrar kodlama yapılması tavsiye edilmektedir. Bu formül sonucuna göre \%80'e yakın bir örtüşme ilk kodlama ile yeniden kodlama arasındaki yüksek bir güvenilirliği göstermektedir. Bu bağlamda araştırmacı ve diğer uzman kişi tarafından araştırmanın geçerlilik ve güvenilirliğini artırmak amacıyla aynı işlem 15 gün ara ile tekrarlanmıș, kodlarda \%85'lik örtüşme olduğu görülmüștür.

\section{Bulgular}

Araştırmada ele alınan televizyon programlarının içerikleri incelendiğinde modern yaşamın getirdiği çalışma zamanları, boş zaman faaliyetleri, tüketimin yaşam amacı haline gelmesi, betonlaşma, şehirleşme, sağlıksız beslenme ve yaşam koşullarını sorgulayarak tüketim toplumunun bir parçası olmayı reddeden üretim odaklı yaşamı ön plana çıkaran şehirlerden köylere yönelmiş yeni yaşam biçimlerinin hikâyeleri 
anlatılmaktadır. Tüketim karşıtlığının farklı boyutlarında yeni yaşam modeli olarak köye dönüşün sunulduğu programlarda yer alan kodları analiz etmeye yönelik yapılan çalışmada ortaya çıkan veriler temalar altında yorumlanarak, programların tüketimcilik, doğal yaşam, sürdürülebilir üretim ve tüketim, șehir yaşamına ilişkin konularda şehirde yaşayan tüketicilere, köyde yaşayan tüketicilere ve işletmelere yönelik mesajlar içerdiği belirlenmiştir.

Tablo 1: Şehirde Yaşayan Tüketicilere Yönelik Mesajlar

\begin{tabular}{|l|l|}
\hline \multicolumn{2}{|c|}{ Ana Tema: Şehirde Yaşayan Tüketicilere Mesajlar } \\
\hline Alt Temalar & Kodlar \\
\hline Tüketimcilik & Sınırsız kredi kartı ve alışveriş, Aşırı tüketim, Gereksiz eşyalar \\
\hline $\begin{array}{l}\text { Yabancılaşma } \\
\text { (Özüne/doğaya) }\end{array}$ & $\begin{array}{l}\text { Ürünlerle yaşamı devam ettirebilme ve kolaylaştırma, Tüketime } \\
\text { Alıştırıma, Doğal Yaşamın Marjinal Görünmesi, }\end{array}$ \\
\hline Yaşam Felsefesi & $\begin{array}{l}\text { Aç Gözlülük Yok Aşırılık Yok, Basit Sade Derin Yaşama, Birlikte Hareket Etme, Çok } \\
\text { Mala Sahip Olmadan Huzur Ve Mutluluk, Elindekilerle Yetinme, Kendi Ürünü Yetiştirme }\end{array}$ \\
\hline Köyde Yaşam & $\begin{array}{l}\text { Köylülerle Bilgi Alışverişi, Komşuluk, Takas Sistemi, Bolluk, Dayanışma } \\
\text { Kültürü İmece, Yaşam Daha Ucuz, Organik Beslenme }\end{array}$ \\
\hline $\begin{array}{l}\text { Doğanın Güzellliği } \\
\text { ve Yaşam }\end{array}$ & $\begin{array}{l}\text { Oksijen Kaynağı, Yeşil Ve Mavinin Türlü Flörtü, Endemik } \\
\text { Bitki Türü Zenginliği, Sıfır Teknolojik Ses Sağlık, }\end{array}$ \\
\hline $\begin{array}{l}\text { Şehirde Yaşam } \\
\text { Kalabalık, Yorucu, Otoparkta Yer Bulamama, Kırmızı Işıkta Bekleme, Yaşam } \\
\text { pahalıı̆ı̆ı, Şehrin Standart Yaşam İmkanları Köye Göre Oldukça Lüks }\end{array}$ \\
\hline
\end{tabular}

Program içeriklerinde șehirde yaşayan tüketicilere verilen mesajlara bakıldığında, huzurun ve mutluluğun çok mala sahip olmaktan daha önemli olduğu sağlıklı bir yaşam için insanın özüne dönerek kendi ürettiği ya da geleneksel yöntemlerle üretilmiş ürünleri tercih etmesinin faydalı olacağı konuları ön plana çıkmaktadır. Organik beslenme, şehirde yaşamanın zorlukları, doğanın güzelliği ve doğada yaşamanın avantajları gibi kodlar programlarda sıklıkla yer almaktadır. Programlarda farklı hikâyelerde ortaya çıkan ve şehirde yaşayan insanların köylerde yaşama fikrini benimsemesini sağlayabilecek nedenler şu şekilde sıralanmaktadır: köydeki ürün bolluğu; sağlıklı gıda, su, barınma ihtiyacı; toprağa temas etme; tüketilen gıdaların ve kullanılan nesnelerin olumsuz sonuçlarının farkına varma; doğaya ve özüne dönüş isteği; profesyonel iş yaşamı ve doyum; üretmeden tüketmenin verdiği huzursuzluk. Tüketim kültüründe misafir ağırlamak gösterişli bir ritüelin parçası haline gelebiliyor. Özel çatal kaşıklar, tabaklar, bardaklar, peçeteler, özel sunumlar misafire verilen değeri temsil eden maddi yapılar haline dönüşmektedir. Sosyalleşmenin, kimliklenmenin, kabul görmenin, sevginin ve değer vermenin karşılığı haline gelen bu aşırı tüketim hali șehir yaşamını zorlaştıran unsurlardan biridir.

\footnotetext{
Z.K.: “......Bugün salatalığımız, domatesimiz kendi yiyeceğimiz çıkıyorsa, salatalığın turşusunu yapabiliyorsak bir çuval da unumuz varsa bizden mutlu kimse olmaz yani bugün misafirin geldiğinde sütünden peynir yapmışsındır tereyağın vardır.....", "işte çok küçük şeylerle misafirini ă̆ırlayabiliyorsun ama șehirde öyle bir şansın yok cebinde paran yoksa hastayım diyeceksin seyahatteyim diyeceksin bir araya gelemeyeceksin, burada kuru kumanyan varsa geçim sıkıntı değil"
}

Programda verilen mesajlarda şehirden köye gelenler/gelecekler için karşılaşabilecekleri önyargılı bakışlar tanımlanmıştır. Şehirden köye gelenlerin neden rahatını bırakıp geldiğini köylüler anlamlandıramayarak önyargı ile yaklaşmaktadır. Köylerine gelen şehirlilere bakışlarında "burada köyde yaşayamaz", "bunlar şehirde kafayı yemişler gelmişler", "altın araştırmacısı”, "arsa spekülatörü”, “ yazlık villa müteahhiti”, "kültürel yozlaşma", "burayı yok edecekler" şüpheleri söz konusu olmaktadır. Bu durum aslında insanların şehirdeki tüketim odaklı yaşamı normalleştirip doğadaki üretim odaklı yaşamı 
yabancılaștırmasının bir sonucu olarak da görülebilir. Tüketim toplumunda yaşam, insanlara doğal hayatta nasıl yaşayacaklarına ilişkin bilgi ve beceriden uzaklaştırarak gündelik hayatı kolaylaştıran ya da tamamlayan ürünlerle ihtiyaçların karşılandığı otomatik bir düzen yaratmıștır. Üreten toplumdan tüketen topluma doğru bir değişim yaşanmaktadır buna tepki olarak tüketim karşıtı eğilimler program içeriklerinde kendini göstermektedir.

B.E. : "Sürekli çalışacaksınız ama karşılığında ürün diye sunulan o kadar sağlıksız ki, plastik şişede su, genetiği değiştirilmiş gıda ve beton duvarlar arasında bir yaşam"

İ.Y.: "Şehirde yaşayan bu sistemin insanlara öğretmeye çalıștığı "evlen ev al, araba,al" gibi biz bunları bol bol yaptık tabi. Çocuklarımız oldu evlerimiz oldu arabalarımız oldu filan sınırsız kredi kartları, sınırsız alışveriş ekonomik baskı olmaksızın bir yaşam sürerken bir yerde bir yanlış olduğunu farkettim."

Programda yapılan doğa tasvirleri, șehrin gürültüsü, karmaşası, kirliliği ve bekleme kuyrukları karşısında şehirde yaşayanlara yönelik bir davet mesajı göndermektedir

E.K.: "Doğanın kendine özgü gizemli, tahmin edilemez bir ruhu var.....sabredip kulak kesilenlere büyüleyici bir hikaye anlatıyor. Örneğin hiç bitmeyecekmiş gibi yağan yağmurun ardından çıkan gökkuşağı ömrümde gördüğüm en büyüleyici gökkuşağıydı bir süre nefessiz bu manzarayı izledim."

Programlarda sürdürülebilir tüketim alt teması kapsamında genel olarak topluma iletiler gönderilmektedir. Sürdürülebilir tüketim kapsamında neye ihtiyacı olduğunun farkında olarak tüketim bilincine sahip olma, kendi ürünü üreterek kendi kendine yeten bir düzen oluşturma, sürdürülebilir malzemelerin kullanılması, sürdürülebilir enerjinin kullanılması tarımsal faaliyetlerin sürdürülebilirlik ilkesi dikkate alınarak gerçekleştirilmesi önerilmektedir. Bu mesajlar her kesimden tüketiciler açısından dikkate alındığında sürdürülebilir bir tüketim düzeyi için hem tüketim biçiminin hem de tüketilen ürünlerin niteliğinin değişimini gerektirmektedir. Tüketicinin kullandığı ürünün daha az enerji tüketmesi sürdürülebilir enerji açısından anlamlı olacak ve tüketici için tercih nedeni olabilecektir.

Tablo 2: Topluma Yönelik Mesajlar

\begin{tabular}{|l|l|}
\hline \multicolumn{2}{|c|}{ Ana Tema : Topluma Yönelik Mesajlar } \\
\hline Alt Temalar & Kodlar \\
\hline $\begin{array}{l}\text { Sürdürülebilir } \\
\text { Tüketim }\end{array}$ & $\begin{array}{l}\text { Kendi kendine yeten düzen, Sürdürülebilir tarım, Atık yönetimi, Neye intiyacı } \\
\text { olmadığını bilmek, Sürdürülebilir enerji kullanımı, Sürdürülebilir malzeme }\end{array}$ \\
\hline $\begin{array}{l}\text { Sürdürülebilir } \\
\text { Üretim }\end{array}$ & $\begin{array}{l}\text { Organik tarım, Markasız paketler, Doğal ürünler, } \\
\text { Permakültür, } \\
\text { Kendin üret ürettiğin kadarını tüket. } \\
\text { Geri dönüşümden yapılan eşyalar, Sürdürülebilir tarım }\end{array}$ \\
\hline Köyde Yaşam & $\begin{array}{l}\text { Tarımsal üretimi türeterek intiyaçları karşılama, } \\
\text { Dayanışmaya, yardımlaşmaya ve paylaşıma dayalı bir kültür }\end{array}$ \\
\hline
\end{tabular}

Günümüz değişen yaşam şartları kavramları yeniden tanımlayarak yeni anlamlar yüklemiştir. Bu bağlamda şehir yaşamı "yeniyi" ve "tüketimi", köy yaşamı ise "eskiyi" ve "üretimi" temsil etmektedir. Eski șehirliler "yeni köylü" olmuş, köylüler de eski zamanlardaki gibi köylü değil "yarı şehirli” hale gelmiştir.

Ş.Y.: Yazın çay toplamaya findık toplamaya büyükler geliyor, topluyor ve gidiyor. Çocuklar köy yaşantısını bilmiyorlar. Köyde ne oldu ne bitti annem babam nasıl çalıștı çocuklarının haberi yok, çocuklar internet kafeye gidiyor, alışverişe gidiyor ondan sonra evde oturuyor. 
Programda sunulan hikâyelerdeki köye dönen "yeni köylüler", kurumsal hayatı yaşamış bu yaşamdan doyumunu almış kişiler belki bu nedenle şehir hayatına bakışları köylülerin şehre özenen bakışlarından oldukça farklıdır. Bu noktada tüketim bilincine sahip yeni tüketici profilini yansıttıkları görülmektedir.
E.K.: "Çiftlik hayatında daima güzel olan bir şey var o da topraktan ve doğadan sofraya gelen yiyecekler, masanızdaki her şeyin her zaman doğal, taze ve hormonsuz olduğunu düşünün, insan bu sofrada gençleştiğini hissediyor. Mutfak raflarına ilk bakışta insanın dikkatini markasız paketler çekiyor çünkü burada doğanın kendisi bir süpermarket...."
B.E.: "marketten gözünüzü doğaya çevirdiğinizde yiyecek pek çok şey buluyorsunuz zaten"

Tüketim toplumunda kullan at mantığı egemendir. Elden çıkarılan eşyaların birilerinin bir ihtiyacını gidermesi yerine herkesin yeni ürünler satın alarak ihtiyaçlarını karşılaması tercih edilir. Bauman (2018, s.254-255), tüketim toplumunun temel ayrımının ihtiyaçların esnekleşmesi olarak anlatır. İhtiyaçların sınırlarının kalkması, nesnelerin yarattığı yoksunluğun yarattığı gerginliği canlı kılarak tüketim toplumu bireylerini hareket halinde tutup tatmini imkânsız hale getirmektedir

B.Y.: "Bir de ben şeyi anlamıyorum ne kadar çok lüzumsuz eşyamız varmış yani arkadaşlara açık ev yaptık çağırdık ver Allah ver sat ver yok 50 tane gömlek, bilmem kaç tane takım elbise hiçbirisi gerekli değilmiş bir tanesini tuttum hiç giymemişim."

E.K.: Bu şehir göçmeni bilgisini köye getirmiş, köyden de çok şey öğrenmiş öğrenecek çok şeyi olduğunu biliyor kesin olarak bildiği şey ise neye ihtiyacı olmadığı.

Tablo 3:Köyde Yaşayanlara Yönelik Mesajlar

\begin{tabular}{|l|l|}
\hline \multicolumn{2}{|c|}{ Ana Tema : Köyde Yaşayanlara Yönelik Mesajlar } \\
\hline Alt Temalar & Kodlar \\
\hline Sürdürülebilir Üretim & $\begin{array}{l}\text { Yeni çiftlik modelleri, organik tarımla katma değeri yüksek } \\
\text { ürünler üretebilme, permakültür, doğal geri dönüşüm sistemi }\end{array}$ \\
\hline Tarım İlacı & $\begin{array}{l}\text { İlaç Kullanımı Kolay ama Zararlı. } \\
\text { Piyasa Koşullarının Endüstriyel Tarıma Yönlendirmesi } \\
\text { İlaçlama yerine bitkisel çözümler }\end{array}$ \\
\hline Devlet Desteği & $\begin{array}{l}\text { Kırsal kalkınmada devlet tarım destekleri, Üniversite } \\
\text { bakanlık ve Avrupa Birliği işbirliğinde proje destekleri }\end{array}$ \\
\hline Verimlilik & $\begin{array}{l}\text { Kendi kendine yeten düzen, } \\
\text { Organik ürünlerin yüksek fiyatla satışı } \\
\text { Atık yönetimi }\end{array}$ \\
\hline
\end{tabular}

Tablo 3. Köyde yaşayanlara yönelik mesajlar incelendiğinde sürdürülebilir üretim teması kapsamında kamu kurumlarının sağladığı destekler, organik üretimin avantajları, tarım ilaçları yerine bitkisel çözümler ve geri dönüşüm sistemine ilişkin bilgiler sunulmaktadır.

Tarımsal üretimde kullanılan ilaç, gübre gibi kimyasalların olumsuz etkilerinin insan ve toplum sağlı̆ı üzerindeki zararları artarak kendini göstermektedir. Bu olumsuz etkilerin en aza indirilmesi için kimyasal gübre ve tarımsal savaş ilaçlarının hiç ya da mümkün olduğu kadar az kullanılması, bunların yerini aynı görevi yapan organik gübre ve biyolojik savaş yöntemlerinin kullanılmasına dayanan Ekolojik Tarım uygulamaları geliştirilmiştir (Erkmen ve Özdemir, 2012, s. 28). Tarımsal üretimde kullanılan ilaçlar ve hayvancılıkta kullanılan yemler ve katkı maddelerinin büyük oranda ithal edildiği dikkate alındığında ekonomik göstergelerdeki değișimler çiftçilerin maliyetlerini arttırmaktadır (Donat, 2018). Program içerikleri incelendiğinde sunulan hikâyelerde köyde yaşayanlara bu noktada kendi kendine yeten bir düzen ya da geri dönüşüm sistemi kurarak organik tarımla doğaya uyumlu üretimle maliyetleri azaltıp daha yüksek ekonomik getiri sağlamayı önerdikleri görülmektedir. 
B.Y.: "biz tamamen kimyasalsız, GDO’suz doğal tarım yapıyoruz buna ilk bașta öyle yan bakıyorlardı "verimi kaçar onun" diyorlardı şimdi verimi belki onlarınki 1'e 11, bizimki 1'e 5veriyor fakat mukayese imkanı yok çünkü ben satıyorum kilosunu 5 liradan, onlar satıyor kilosunu 70 kuruştan muazzam bir fiyat farkı var."

E.K.: Yalnızca biz değil çiftlikteki hayvanlar da organik besleniyor, hiçbir şey ziyan edilmiyor, müthiş bir geri dönüşüm var. Tavuklar kendi yumurtalarının kabukları ve artan besinlerden oluşan bir çeşit salatayla besleniyor.

K.: Biz burada hiçbir şeyi ziyan etmiyoruz. Hayvanlar tüm atıkları yiyor.......

R.Y.: "burada önemli olan doğaya zarar vermeden, çok tüketici olmadan teknolojiyi de kullanabilmek aslında teknolojinin karşısında ille de hayatımızı zorlaştıracağız diye bir düşüncede de değiliz. Bir çamaşır makinemiz olsa mesela güneşten enerjimizi sağlıyoruz kendi deterjanımızı yapıyoruz"

Programda verilen mesajlara bakıldığında hem sağlıklı hem doğayla dost bir şekilde teknolojik imkânlardan da yararlanarak yaşamanın mümkün olacağı belirtilmektedir.

Günümüzde, tüketicilerden giderek artan bir biçimde, tüketici kapitalizminin sert olmasının ve ahlaki boşluğunun ötesine bakmaları, isyan, özgünlük, sadelik, ekonomik adalet ve ekolojik sorumluluk damgası taşıyan bir dizi niş pazarlı üründe daha geniş yaşam sorunları için daha derin anlamlar aramaları istenmektedir (Binkley, 2008, s. 599). Tüketici-vatandaş sorumluluğunu yerine getirmek isteyen tüketiciler dikkate alındığında farklı ve büyüyen bir pazar olarak da görülmektedir. Choi (2011, s. 117), tüketim karşıtlığının artık niş tüketicilerin küçük bir akışı olmadığını pazarın genelinde büyük bir trend haline geleceğini ileri sürerek işletmelerin bu eğilimi dikkate alarak yeni firsatlar bulmaları ve stratejik tepkiler düşünmeleri gerektiğini belirtir. Bu bakış açısı karşılığını bulmuştur, 1990'lardan günümüze bir çok küresel şirket sürdürülebilirliği sağlama adına çevre dostu ürünler sunmaktan toplumun çevre duyarlılığını arttıracak programlar düzenlemeye kadar farklı boyutlarda faaliyetler yapmaktadırlar (Esty ve Winston, 2008; Kotler, Kartajaya, Setiawan ve Dündar, 2010, s. 165-178).

Tablo 4: Isşletmelere Yönelik Mesajlar

\begin{tabular}{|l|l|}
\hline \multicolumn{2}{|c|}{ Ana Tema : İşletmelere Yönelik Mesajlar } \\
\hline Alt Temalar & Kodlar \\
\hline Paradigma Dönüşümü & $\begin{array}{l}\text { Müşteri değil ortak, } \\
\text { Satış değil paylaşım }\end{array}$ \\
\hline Ürün & $\begin{array}{l}\text { Tamamen organik özel ürünler } \\
\text { Kişisel gelişim, kültürel ürünler } \\
\text { İnsan sağlığı açısından en besleyici ürünler }\end{array}$ \\
\hline Hedef Kitle & $\begin{array}{l}\text { Köy yaşamını deneyimlemeyi arzulayan meraklı şehirli tüketiciler, } \\
\text { Sağlıklı yaşam meraklısı, } \\
\text { Geleneksel kültürü deneyimlemek isteyen tüketici }\end{array}$ \\
\hline
\end{tabular}

Farklı şehirlerde yer alan bir çok ekolojik yaşam yada perma kültür yada sadece çiftlik adıyla kurulmuş birimler bu alternatif arayan şehirli (köylülere) yeni bir üretim ve tüketim alanı açarak farklı bir işletmecilik modeli olarak da yeni bir pazar fırsatına dönüşmektedir. Lee, Fernandez \& Hyman (2009, s.145), İş dünyasının ve akademisyenlerin, tüketim karşıtı eylemleri ürünler, uygulamalar ve toplum hakkında bilgi edinme firsatı olarak görmeleri gerektiğini belirtiyor.

Sunucu G.İ.: A. Çifti, çiftliği çok amaçlı bir yer haline getirmeye çalışıyor eğitim atölyeleri gibi özellikle de peynir yapım atölyeleri. B. Hanım deneyimlerini insanlarla paylaşıp bu peynirin evde tek başına nasıl yapılacağını anlatacak. Çiftimiz deneyimlerini paylaşmak için daha büyük bir yer yapıyor, insanlar gelecek, burada kalacaklar bir çiftlikte hayatın nasıl olduğunu 
görecekler, gönüllü olarak çalışacaklar yada sadece gelip atölye çalışmalarına katılacaklar sonuçta bu hayatı isteyip istemediklerine karar verecekler."

Köylerde oluşan eski tüketici yeni üretici bireylerin uyguladığı üretim modeli aslında bir iş modelini ve bu bağlamda yeni iş fırsatlarını da beraberinde getirmektedir. Şehirde yaşayan fakat devamlı olarak köy hayatını sürdüremeyecek insanlara "hem o hem bu" postmodernist telkiniyle(Odabaşı, 2006, s. 64) köy yaşamını deneyimleme (kırsal turizm yada ekolojik turizm) (Papatya, Papatya ve Özdemir, 2011) ve organik yada yöresel ürünleri satın alabilme imkanını sunmaktadır. Bu uygulamalar sadece tüketim karşıtlığının bir boyutunda çevreye duyarlı ve doğaya dost tüketicilerinin tepkilerini karşılamaktadır. Bununla birlikte programlarda sunulan hikâyelerdeki mesajlar incelendiğinde köylerde ya da doğada yaşamanın hem doğal yaşam alanının kısıtlığı, doğal yaşamın zorluğu, kişilerin doğal yaşam becerilerinden yoksunlukları ve şehrin konforundan vazgeçememe gibi nedenlerle her şehirli tarafından gerçekleştirilemeyeceği belirtilmektedir. $\mathrm{Bu}$ noktada işletmelerin bu ihtiyacı karşılamaya dönük yeniden bir bakış açısı kazanması ve hedef kitle tanımı, yeniden ürün tasarımı ve fiyat stratejisi geliştirmeleri gerekmektedir. Bununla birlikte tüketim karşıtı bir kısım tüketicinin eski arzu ve isteklerini eleştirip yeni arzu ve isteklere yönelmesi farklı bir okumayla değerlendirilirse, Baudrillard'ın eleştirisine katılmamak mümkün değildir. Baudrillard tüketim karşıtı söylemleri şöyle eleştirir:

\begin{abstract}
Kendisine saygı duyan her büyük söylen gibi "Tüketim" in söyleni de söylemine ve karşı söylemine sahiptir, yani tüketim üzerine yüceltilen söyleme, her yerde tüketim toplumunun kötülükleri üzerine ve bu toplumun uygarlığın bütünü için kaçınılmaz olarak taşıdığı trajik sonuç üzerine "eleştirel", "hırçın ve ahlakçı" bir karşı-söylem eşlik eder............Bu karşı söylemin de tüketim toplumunun diğer tüm özellikleri kadar tüketim toplumuna içkin olduğunu söyleyeceğiz (2004, s. 256-257)
\end{abstract}

İşletmeler sosyal, kültürel, teknolojik ve çevresel faktörleri ve bu alanlardaki değişimleri dikkate alarak kararlarına yön vermek durumundadır. Pazarda tüketici istek ve ihtiyaçlarını tahmin ederek ve daha önemlisi yaratarak başarı sağlanabilir bu açıdan tüketicilerin gelecek eğilimleri oldukça önemlidir. Bununla birlikte sadece tüketiciler yönüyle değil finansal alanda giderek önem kazanan bir eğilim olarak sosyal sorumlu yatırım (Gök, Özdemir ve Ünlü, 2019) anlayışı kapsamında yatırımcıların aldıkları kararlarda sürdürülebilirlik kriterlerini sağlayan şirketler tercih edilmektedir. Böylelikle bu şirketler hem prestij sağlarken hem de daha kolay kaynak sağlayabilmektedirler.

\title{
Sonuç
}

Tüketicilerin tüketim karşıtı eğilimleri maddi tüketimi reddetme, tüketimi sınırlama, reklam mesajlarına karşı olma, markaları boykot etme, medyanın sunduğu tüketim kalıplarını reddetme, gönüllü sade yaşamı ve sürdürülebilir tüketimi benimseme noktasında farklı boyutlarda görülmektedir. Tüketimi reddederek yada kısıtlayarak mevcut duruma alternatif bir yol üreten bireyler toplumsal ve kültürel değişimi sağlamada bir değișim ajanı rolünü üstlenmektedir. Tüketim karşıtı söylemler tüketime bakış açısının değişimini sağlayarak tüketicileri bir vatandaş olarak daha sorumlu olmaya bu kapsamda sürdürülebilir tüketim anlayışına yönlendirmektedir. Tüketim karşıtı söylemlerin ve bu doğrultudaki günlük yaşam pratiklerinin medyada görünürlüğünün artması bu konudaki ilgiyi de arttırmaktadır.

Araştırma kapsamında içerik analizi yapılan televizyon programlarında şehirde yaşayan tüketicilere, topluma, köyde yaşayan tüketicilere ve işletmelere yönelik mesajlar içerdiği tespit edilmiştir. Program içerikleri çözümlendiğinde şehirde yaşayan tüketicilere 
insanların bilinçsizce aşırı tüketim yaptığı ve şehir yaşamı iş hayatı ekseninde bunun farkına varılmadan sürdürülemez tüketim odaklı bir yaşam devam ettirildiği mesajları kişilerin kendi yaşam hikâyeleri üzerinden anlatılmaktadır. Bu yaşama alternatif olarak sunulan köyde yaşama sürecinde, karşılaşılan zorluklar, güzellikler, köyde yaşamanın olumlu-olumsuz yönleri, köydeki üretim ve tüketim, șehirden gelen insanlara önyargılı yaklaşımlar ele alınmaktadır.

Program içeriklerinde sunulan yeni üretim ve tüketim biçimleri tüketim karşıtlı̆̆ kapsamında yeni yaşam biçimlerini ortaya çıkarmaktadır. Araştırma bulgularına göre program içerikleri yeni bir tüketici profili tanımlamaktadır. Buna göre bu yeni tip tüketici doğaya ve insana karşı sorumluluk ve saygı duyan, tüketim bilinci yüksek, istek ve arzuları ekseninde haz ilkesiyle değil sınırlı ve sade bir yaşamı benimseyen, geçmiş yaşam bilgilerini edinerek onu yaşatmaya çalışan, kendi ürününü üreterek kendi kendine yeten bir düzen yaratan, huzur ve mutluluğu çok mala sahip olmadan sade ve derin yaşamda, dayanışma ve paylaşma kültüründe bulan özellikler sergilediği ortaya çıkmıştır. Program içeriklerine bakıldığında tüketimi tamamen reddederek ihtiyaçlarını karşılayacak üretimi kendisi gerçekleştiren bir örnek ile birlikte diğer örneklerde sade yaşam kapsamında kendi ürettiğini tüketen daha sınırlı bir tüketim odaklı yaşam anlatılmaktadır. Bu yeni tüketici tipinin tüm tüketiciler içinde ne kadarlık bir kesimi temsil ettiği tam olarak bilinmemekle birlikte kitle iletişim araçlarının etkisiyle yaygınlaşarak günümüz tüketim eğilimleri içinde giderek popülerleşeceği düşünülmektedir. Buna örnek olarak gönüllü sadeliğin bir boyutu olarak minimalizm akımı kapsamında minimal tüketim gösterilebilir. Yaşam koşulları, yetenekler ve imkânlar dikkate alındığında tüketicilerin büyük çoğunluğunun, bu yeni tüketici özelliklerini tatmin eden yaşam biçimini sağlayabilmeleri tam olarak mümkün görünmemektedir. Fakat bazı ürün ya da hizmetlerin deneyimlenmesi örneğin şehirde yaşayan tüketicilerin bir kısmının tatil tercihlerini ekolojik köylerde öğrenme ve deneyim odaklı olarak gerçekleştirmesi bu hassasiyetlerin belirli oranda tatmin edilmesini sağlamaktadır. Programda yer alan ifadelerin de desteklediği gibi yeni tüketiciler için her zaman bu hassasiyetler doğrultusunda yaşamak çok kolay olmayabilir:

R.Y.: "Doğada yaşamak çok da romantik değil, soba tütebilir yanmayabilir o sırada buz gibidir hava ........s.sehirde öyle olmayabiliyor bir yolunu bulabiliyorsun bu nedenle niye burada olduğunu bilmek lazım ki zorlukları da hayatına sokabilesin."

Tüketim karşıtı eğilim topluma ve çevreye karşı sorumluluklar ekseninde tüketicinin birey olarak bunu bir vatandaşlık görevi gibi algılayıp özellikle sürdürülebilir tüketim çerçevesinde hareket etmesini sağlayabilir. $\mathrm{Bu}$ anlayış, tüketicilerin gerçek anlamda tüketim kararlarında ve günlük yaşamlarında bilinçli ve sorumlu davranmasına yol açabilir ya da aksine tüketim karşıtı söylemler, tüketim toplumunun bir devamı olarak tüketicinin yeni kimliğinin bir parçası haline gelebilir. $\mathrm{Bu}$ durumda bu kimliği tamamlayacak yeni ürün ve hizmetler grubunun sunulmasılya tüketicinin topluma ve çevreye karşı sorumluluğu tatmin edilerek tüketicinin üst benliğinin (vicdanının) memnun olması sağlanabilir.

\section{Kaynakça}

Akar, M., (2018), Tüketim Ahlakı Ve Íktisatlı Olmak,29-45 (Edt : Erdem, E. \& Şahin, H.,.) İsraf Dengeyi Ve Ölçüyü Kaybetmek, Ankara: Diyanet İşleri Başkanlığı Yayınları-1481.

Aksoy, M. ve Solunoğlu, A. (2015), Gıda İsrafı Ve "Freegan Food Akımı". I. Eurasia International Tourism Congress: Current Issues, Trends, And Indicators (EITOC), 165-172 
Ashraf, M. A., Joarder, M. H. R. ve Ratan, S. R. A. (2019). Consumers' Anti-Consumption Behavior Toward Organic Food Purchase: An Analysis Using SEM. British Food Journal, 121(1), 104-122.

Baudrillard, J.(2004), Tüketim Toplumu (Çev. Ferda Keskin ve Nilgün Tutal), İkinci Baskı İstanbul: Ayrıntı Yayınları.

Bauman, Z. (2018). Kuşatılmış Toplum. (Çev. Akın Emre Pilgir). İstanbul: Ayrıntı Yayınları.

Bayat, M.ve Sezer, A. (2018). Bireylerin Gönüllü Sade Yaşam Tarzlarıve Yaşam Doyumlarının, Geleneksellik Değeri Açısından Değerlendirilmesi: Düzce Üniversitesi Örneği. İş Ahlakı Dergisi, 11(1), 69-87.

Binkley, S. (2008). Liquid Consumption: Anti-Consumerism And The Fetishized DeFetishization Of Commodities. Cultural Studies, 22(5), 599-623.

Binkley, S. ve Littler, J. (2008). Introduction: Cultural Studies And Anti-Consumerism: A Critical Encounter. Cultural Studies, 22(5), 519-530.

Black, I. R. ve Cherrier H. (2010). Anti-Consumption As Part Of Living A Sustainable Lifestyle: Daily Practices, Contextual Motivations And Subjective Values. Journal of Consumer Behaviour 9.6, 437-453.

Bozkurt, V. (2005). Endüstriyel Ve Post-Endüstriyel Dönüşüm: Bilgi, Ekonomi Ve Kültür, Aktüel Yayınları Alfa Akademi : İstanbul.

Chatzidakis, A. ve Lee, M. S. (2013). Anti-Consumption As The Study of Reasons Against. Journal of Macromarketing, 33(3), 190-203.

Cherrier, H. ve Gurrieri, L. (2013). Anti-Consumption Choices Performed In A Drinking Culture: Normative Struggles And Repairs. Journal of Macromarketing, 33(3), 232244.

Cherrier, H. (2009). Anti-Consumption Discourses And Consumer-Resistant Identities. Journal of Business Research $62.2: 181-190$.

Choi, S. H. (2011). Anti-Consumption Becomes A Trend.” Seri Quarterly. 4.3: 117.

Craig-Lees, M. ve Hill, C. (2002). Understanding Voluntary Simplifiers. Psychology \& Marketing, 19(2), 187-210.

Dobson, A. (2003). Citizenship and the Environment, USA: Oxford University Press, ProQuest EbookCentral,https://ebookcentral.proquest.com/lib/suleyman-ebooks/detail. action?docID=3052352

Donat,İ. (2019).“Çiftçinin Yem İle İmtihanı”,31Mayıs2018 Perşembe, https:// www.bloomberght.com/yorum/irfan-donat/2125882-ciftcinin-yem-ileimtihani/07.08.2019.

Elgin, D. ve Mitchell, A. (1977). Voluntary Simplicity. Planning Review, 5(6), 13-15.

Erkmen, J., \& Özdemir N. (2012).Organik Gübre Kullanımının Yaygınlaştırılmasında Biogaz Üniteli Süt ve Besi Üretim Çiftlikleri Vasıtası ile ile Sözleşmeli Çiftçilik Modelinin Uygulanabilirliği. Karadeniz Fen Bilimleri Dergisi, 3(1), 27-38.

Esty, D. C. Ve Winston, S. A. (2008). Yeşilden Altına Akıllı Şirketler Çevreci Stratejiler İle Nasıl Avantaj Yaratır?(Çev. L. Göktem). İstanbul: MediaCat. 
Fournier, S. (1998). Special Session Summary Consumer Resistance: Societal Motivations, Consumer Manifestations, And Implications In The Marketing Domain. ACR North American Advances.

Geray, H., (2006), Toplumsal Araştırmalarda Nicel Ve Nitel Yöntemlere Giriş İletişim Alanından Örneklerle. Geliştirilmiş 2. Baskı. Ankara:Siyasal Kitabevi.

Gok, I. Y., Ozdemir, O. ve Unlu, B. (2019). The Effect Of Corporate Sustainability Practices On Financial Performance: Evidence From Turkey. In Cases On Corporate Social Responsibility And Contemporary Issues In Organizations (pp. 52-70). IGI Global.

Hoffmann, S. ve Lee, M. S. (2016). Consume Less And Be Happy? An Introduction To The Special Issue On Anti-Consumption And Consumer Well-Being. Journal of Consumer Affairs, 50(1), 3-18.

Iyer, R. ve Munch J. A. (2009). Purpose And Object Of Anti-Consumption." Journal of Business Research. 62.2: 160-168.

Jackson, T. ve Michaelis, L. (2003). Policies For Sustainable Consumption. Sustainable Development Commission, London.

Kotler, P., Kartajaya, H., Setiawan, I. ve Dündar, K. (2010). Pazarlama 3.0: Ürün, Müşteri, İnsan Ruhu. İstanbul: Optimist Yayım Dağıtım.

Kozinets, R.V., Handelman J. M. ve Lee S. M. (2010). Don't Read This; Or, Who Cares What The Hell Anti-Consumption İs, Any Ways?. 225-233.

Krishnamurthy, S. ve Kucuk, S. U. (2009). Anti-Branding On The Internet. Journal of Business Research, 62(11), 1119-1126.

Lasn, K. (2004). Kültür Bozumu. (çev. Cem Pekman ve Ahmet Ilgaz). İstanbul: Bağımsız Yayınları

Lee, M. S., Fernandez, K. V. ve Hyman, M. R. (2009). Anti-Consumption: An Overview And Research Agenda. Journal of Business Research. Volume 62, Issue 2, Pages 145-147

Lee, M., Roux, D., Cherrier, H. ve Cova, B. (2011). Anti-Consumption And Consumer Resistance: Concepts, Concerns, Conflicts And Convergence. European Journal of Marketing, Vol. 45 No. 11/12.

Lee, M.S., Cherrier, H., ve Belk R. Journal of Macromarketing Special Issue: Anti-Consumption Research and Society. Journal of Macromarketing. 33.3 (2013): 187-189.

McDonald, S.,Oates, C. J., Young, C. W. ve Hwang, K. (2006). Toward Sustainable Consumption: Researching Voluntary Simplifiers. Psychology\& Marketing, 23(6), 515-534.

McQuail, D., ve Windahl, S. (1993). Communication Models For The Study Of Mass Communications. Routledge.

Miles, M., ve A. Huberman. 1994. Qualitative Data Analysis. 2nd ed. Thousand Oaks, CA: Sage

Nepomuceno, M. V., Rohani, M. ve Grégoire, Y. (2017). Consumer Resistance: From AntiConsumption To Revenge. In Consumer Perception Of Product Risks And Benefits (pp. 345-364). Springer, Cham.

Odabaşı, Y. (2006). Postmodern Pazarlama Tüketim ve Tüketici. İstanbul: Mediacat Yayınları. 
Papatya,N.,Papatya G. ve Özdemir Ş.(2011). Deneyimsel Pazarlama Açısından Isparta İli Ekolojik Köy Turizm Potansiyelinin Etkinleştirilmesine Yönelik Bir Değerlendirme",UETS'11 ve Göller Bölgesi Değerleri Çalıștayı “Turizmde Yeni Ufuklar" Bildiriler Kitabı,1-4 Aralık, s. 459-466

Pentina, I. ve Amos, C. (2011). The Freegan Phenomenon: Anti-Consumption Or Consumer Resistance?. European Journal of Marketing, 45(11/12), 1768-1778.

Portwood-Stacer, L. (2012). Anti-Consumption As Tactical Resistance: Anarchists, Subculture, and Activist Strategy. Journal of Consumer Culture, 12(1), 87-105.

Prothero, A., Dobscha, S., Freund, J., Kilbourne, W. E., Luchs, M. G., Ozanne, L. K. ve Thøgersen, J. (2011). Sustainable Consumption: Opportunities For Consumer Research And Public Policy. Journal of Public Policy \& Marketing, 30(1), 31-38.

Reid, H., ve Taylor, B. (2000). Embodying Ecological Citizenship: Rethinking The Politics Of Grassroots Globalization In The United States. Alternatives. 25(4), 439-466.

Ritzer, G. (2017). Toplumun McDonaldlaştırılması Çağdaş Toplum Yaşamının Değişen Karakteri Üzerine Bir İnceleme. 5. Basım Ayrıntı Yayınları: İstanbul.

Sagoff, M. (2007). The Economy Of The Earth : Philosophy, Law, And the Environment, Cambridge University Press, ProQuest Ebook Central, https://ebookcentral. proquest.com/lib/suleyman-ebooks/detail.action?docID=328912.

Sanne, C. (2002). Willing Consumers-Or Locked-İn? Policies For A Sustainable Consumption. Ecological Economics, 42(1-2), 273-287.

Seyfang, G. (2006). Ecological Citizenship And Sustainable Consumption: Examining Local Organic Food Networks. Journal of Rural Studies, 22(4), 383-395.

Shama, A. (1981). Coping With Staglation: Voluntary Simplicity. The Journal of Marketing, 45(3). 120-134.

UNEP, 2015, Sustainable Consumption and Production a Handbook for Policymakers Sustainable Consumption Global Edition, http://wedocs.unep.org/ bitstream/handle/20.500.11822/9660/-_ sustainable_Consumption_ and_Production_a_Handbook_for_PolicymakersSustainable_Consumptio. pdf?sequence $=2 \&$ isAllowed $=y / 20.08 .2019$

Yıldırım, A., ve Şimşek, H. (2016). Sosyal Bilimlerde Nitel Araştırma Yöntemleri (10. bs.). Ankara: Seçkin Yayıncılık.

Zavestoski, S. (2002a). The Social-Psychological Bases Of Anticonsumption Attitudes. Psychology\& Marketing 19.2 149-165.

Zavestoski, S. (2002b). Guest Editorial: Anti-consumption Attitudes." Psychology\& Marketing 19.2 121-126.

https://www.un.org/sustainabledevelopment/sustainable-consumption-production/ (Erişim: 28.01.2020)

http://baranciftligi.net/,

http://www.hayalimbiciftlik.com,

https://www.imdb.com/title/tt2328964/?ref_=ttpl_pl_tt/24.07.2019

https://www.tatuta.org/ 
https://www.un.org/sustainabledevelopment/sustainable-consumption-production/ (Erişim: 28.01.2020)

https://www.zeytinlibogaz.com 


\title{
Anti-Consumption New Living Form Return to Village Presentation in the Media: A Case of New Villagers
}

\author{
Şefika Özdemir (Asst. Prof. Dr.)
}

\section{Extended Abstract}

Triggered by consumerism, unsustainable overconsumption damages the environment, and the quality of life of the current population and future generations. Anti-consumerism movements range from making product choices with ethical and ecological concerns, by refusing consumption in general or boycotting certain product groups. Consumers' orientation towards these practices involves an understanding which manifest itself in failure to overcome stress, unhappiness and inability to realize themselves with their material and wealth (Zavestoski, 2002a, p. 154). It is possible to list anti-consumption practices as the rejection of images related to the idea of beauty in the media, rejection of material consumption as a means of self-expression, changing consumer behavior with voluntary simplicity and ethical consumption practices, fighting for the mind space occupied by marketing and advertising messages (Zavestoski, 2002b, p. 122). Iyer and Munch (2009) define four types of anti-consumption consumers: global impact consumers, volunteer simplicity, activists, and nonloyal consumers. Lee, Roux, Cherrier, and Cova (2011) evaluates consumer behaviors within the scope of anti-consumption in three groups of reject, restrict, and reuse. In the rejection processes, individuals deliberately and meaningfully remove certain products from their consumption cycles, for example, they choose not to use the Nike brand for functional, symbolic, or ethical reasons. The idea of restriction is to reduce and limit consumption when it is not possible to prevent consumption altogether. Recovery behavior represents an ideological change in purchasing, using, and disposal. For example, those who adopt voluntary simplicity get their identity back through production instead of consumption when they choose to grow their vegetables rather than shopping from traditional vegetable markets. The freeganism trend, which has recently come to the fore as a different form of anti-consumption, refers to a social, economic, and political trend that tries to minimize the environmental impact by consuming the discarded food. They emphasize minimizing waste and consumption and using the available resources correctly and effectively for a sustainable World (Aksoy and Solunoğlu, 2015, p.168-170).

Anti-consumption trends are seen as factors of sustainable consumption behavior in terms of protecting natural resources, preventing pollution, and taking into account ecological impact (McDonald, Oates, Young and Hwang, 2006, p. 6). In recent years, consumers' reduction in consumption, preferring voluntary simplicity life, and anti-brand trends provide a way to ensure that the concept of sustainable consumption is taken into consideration in different circles. Media seems to play an important role in the spread of anti-consumption across large consumer segments. In addition to influencing individuals, media affects individuals' cultures, knowledge, and principles and values of society. The media creates this effect by revealing a series of images, ideas, and evaluations that viewers can choose from (McQuail and Windahl, 1993, p. 98).

In the study, content analysis was preferred because it allows us to reveal previously unclear themes and dimensions in the analysis of qualitative data, and to analyze the collected data in depth. During the analysis process of qualitative data, coding of data, 
finding themes, organizing data according to themes, and interpreting the findings were taken into consideration (Ylldırım \& Şimşek, 2016, p. 242-253). In the context of its contents, the program "Yeni Koylu" broadcast on the TRT Documentary channel, the "Yesil Doga" program broadcast on the CNN TURK channel and the "Bi Ciftlik" program broadcast on the TRT Documentary channel were examined. Due to the limitation of the research, two sections were randomly selected from each program and included in the analysis. Thematic coding was used to analyze the qualitative data that came out by deciphering the program contents. The data that emerged in the study conducted to analyze the codes included in the programs where the return to the village is presented as a new model of life in different dimensions of anti-consumption is interpreted under different themes: under the themes of consumerism, natural life, sustainable production and consumption, city life, and messages for businesses. It is observed that programs include messages for consumers, society, village-based consumers, and businesses in issues related to consumerism, natural life, sustainable production and consumption, and urban life. When looking at the messages in the program given to consumers living in the city, it is seen that the following issues come to the fore:

- peace and happiness are more important than having property

- for a healthy life, it is beneficial for people to return to their essence and prefer products that they produce by themselves or by using traditional methods.

- the city noise, chaos, pollution and waiting in lines as opposed to the beauty of nature

There is a change from the producing society to the consumer society in response to this anti-consumption trends that show up in the program contents. When the messages for the residents of the village are examined, it is seen that the support provided by public institutions, advantages of organic production, herbal solutions instead of pesticides, and recycling systems are presented within the scope of sustainable production theme. There is a new type of consumer who act with a sense of responsibility and respect towards nature and people, who has a high awareness of consumption, adopting a limited and simple life instead of the principle of pleasure in the axis of wishes and desires; and tries to keep it alive by building upon on traditional knowledge, creates a self-sufficient order by producing its own product, finds peace and happiness in plain and meaningful life without possessing many goods, has the culture of solidarity and sharing. The quantity of this new type of consumer is not unknown, and it is not the subject of this research.

It is seen that the production model applied by old consumers and new producers, who started to live in the villages, actually brings a business model and new business opportunities in this context. It offers the opportunity to experience village life (rural tourism or ecological tourism) and to purchase organic or local products for those who live in the city but cannot adopt village life continuously. When evaluated critically, some of the anti-consumption movements continue to promote the consumption ideology through a different discourse with the practices it creates within itself.

Keywords: Consumer Behavior, Anti-Consumption, Media, Sustainable Consumption, Content Analysis. 